\title{
Synthesis, structure, and tuberculostatic activity of dimethyl benzoylcarbonohydrazonodithioates
}

\author{
Katarzyna Gobis $\cdot$ Henryk Foks $\cdot$ Zofia Zwolska $\cdot$ \\ Ewa Augustynowicz-Kopeć • Marek L. Główka • \\ Andrzej Olczak $\cdot$ Michał Sabisz
}

Received: 23 September 2010/ Accepted: 12 July 2011/Published online: 16 August 2011

(C) The Author(s) 2011. This article is published with open access at Springerlink.com

\begin{abstract}
New dimethyl benzoylcarbonohydrazonodithioates were obtained by $\mathrm{CS}_{2}$ addition to arylcarboxylic acid hydrazides and methylation of the formed adduct. The new derivatives were tested for their activity against Mycobacterium tuberculosis. Some compounds exhibited high activity toward sensitive and resistant strains.
\end{abstract}

Keywords Benzohydrazides · Crystal structure . Hydrogen bonds - Tuberculostatic activity .

Structure-activity relationship

\section{Introduction}

Tuberculosis (TB) is one of the most deadly infectious diseases with almost 2 million fatalities a year [1]. Mycobacterium tuberculosis strains are known to express multidrug resistance toward a number of chemotherapeutics and antibiotics (MDR and XDR-TB) [2]. This phenomenon is associated with higher mortality, especially

K. Gobis $(\bowtie) \cdot$ H. Foks

Department of Organic Chemistry,

Medical University of Gdansk, Gdansk, Poland

e-mail: kgobis@gumed.edu.pl

Z. Zwolska · E. Augustynowicz-Kopeć

Department of Microbiology, Institute of Tuberculosis

and Pulmonary Diseases, Warsaw, Poland

M. L. Główka · A. Olczak

Institute of General and Ecological Chemistry,

Technical University of Łódź, Łódź, Poland

M. Sabisz

Department of Pharmaceutical Technology and Biochemistry,

Gdansk University of Technology, Gdansk, Poland for HIV-infected individuals, because of increased risk of the infection progressing to active disease [3]. Thus complex chemotherapy protocols with a combination of different drugs are required. The World Health Organization (WHO) and other organizations including the European Commission (EC) therefore create new directly observed treatment shortcourse (DOTS)-type therapeutic strategies [4]. A different solution to the global problem of tuberculosis consists in farther searching for new targets for tuberculostatic therapeutics and new chemical structures able to overcome M. tuberculosis infections. During the last few years new targets for tuberculostatics have been identified, among others fatty acid biosynthesis, amino acid biosynthesis, and DNA synthesis [5].

The most widely used drug in antituberculosis regimens is isoniazid (INH). Unfortunately mycobacteria become resistant to that drug very quickly, and INH causes serious side effects. These problems are being addressed by various research groups $[6,7]$. For example new potentially active structures have been found among hydrazones $[8,9]$ and arylhydrazones [10]. Some of them exhibit promising tuberculostatic activity [11].

In our previous papers we demonstrated that some INH analogs such as pyridine- and pyrazinecarboxamidrazones exhibit high activity against tuberculosis [12]. Crystal structures of representatives from these classes of compounds have been determined. We have found that all of them are in dipolar form, and intramolecular hydrogen bonds maintain the planar arrangement of atoms of the amidrazone functional group [13-15]. Continuing that research program we have synthesized a series of dimethyl benzoylcarbonohydrazonodithioates. In this work we present the synthesis, promising results of tuberculostatic activity tests in vitro, and crystal structures of two isomeric nitrophenyl derivatives. 


\section{Results and discussion}

\section{Synthesis}

The starting benzohydrazides were obtained from methyl esters in a typical reaction with $100 \%$ hydrazine hydrate. Hydrazides upon treatment with carbon disulfide and a double excess of methyl iodide in a basic environment of $\mathrm{KOH}$ or triethylamine were transformed into the corresponding dimethyl benzoylcarbonohydrazonodithioates 1-14 (Scheme 1).

Reactions were performed in ethanol-water solution at room temperature and occurred with good yields. The structures of the obtained compounds were confirmed by elemental analysis, IR, ${ }^{1} \mathrm{H}$ and ${ }^{13} \mathrm{C}$ NMR spectroscopy, and mass spectrometry (compounds $\mathbf{1}$ and 2); compounds $\mathbf{6}$ and 7 were also unequivocally determined by X-ray diffraction (Fig. 1).

${ }^{1} \mathrm{H}$ NMR spectra and X-ray diffraction provided interesting information about the new compounds. Unexpectedly in some products the two thiomethyl groups are not detected in the ${ }^{1} \mathrm{H}$ NMR spectrum as a singlet of six protons but rather as two singlets of three protons, which indicates the magnetic inequivalence of both groups. Aromatic ring substituents that are able to exert a strong negative inductive effect $\left(\mathrm{NO}_{2}, \mathrm{Cl}\right)$, especially in the 2-position, probably interact with $\mathrm{SCH}_{3}$ groups through space. This interaction (or lack of it) is well illustrated in the monocrystal structure of 2-nitrobenzoylcarbonohydrazonodithioate (6) and 4-nitrobenzoylcarbonohydrazonodithioate (7) (Fig. 1). Crystal data of compound 6 indicate double bond character of bonds $\mathrm{C} 1-\mathrm{N} 2$ and N2-N3. This results in restriction of internal rotation and changes the electron density around protons of only one of the $\mathrm{SCH}_{3}$ groups, resulting in the magnetic inequivalence of both groups. Lack of a substituent or insertion of a substituent exerting a weak negative inductive effect $\left(\mathrm{OH}, \mathrm{OCH}_{3}\right)$ does not cause the aforementioned interaction, and the thiomethyl groups of those compounds

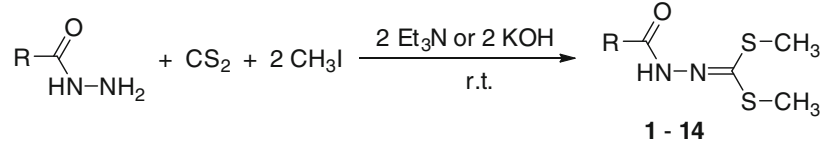

$$
\begin{aligned}
& \begin{array}{c|l|c|l}
\text { No } & R & \text { No } & R \\
\hline \mathbf{1} & \mathrm{Ph} & \mathbf{8} & 2-\mathrm{HO}-\mathrm{Ph} \\
\hline \mathbf{2} & 2-\mathrm{Cl}-\mathrm{Ph} & \mathbf{9} & 3-\mathrm{HO}-\mathrm{Ph} \\
\hline \mathbf{3} & 4-\mathrm{Cl}-\mathrm{Ph} & \mathbf{1 0} & 4-\mathrm{HO}-\mathrm{Ph} \\
\hline \mathbf{4} & 2,4-\mathrm{Cl}_{2}-\mathrm{Ph} & \mathbf{1 1} & 4-\mathrm{CH}_{3} \mathrm{O}-\mathrm{Ph} \\
\hline \mathbf{5} & 3,4-\mathrm{Cl}_{2}-\mathrm{Ph} & \mathbf{1 2} & 3,4,5-\left(\mathrm{CH}_{3} \mathrm{O}\right)_{3}-\mathrm{Ph} \\
\hline \mathbf{6} & 2-\mathrm{NO}_{2}-\mathrm{Ph} & \mathbf{1 3} & 3,4-\left(\mathrm{CH}_{3} \mathrm{O}\right)_{2}-\mathrm{Ph}-\mathrm{CH}_{2} \\
\hline \mathbf{7} & 4-\mathrm{NO}_{2}-\mathrm{Ph} & \mathbf{1 4} & \text { Pyrazin-2-yl }
\end{array}
\end{aligned}
$$

Scheme 1
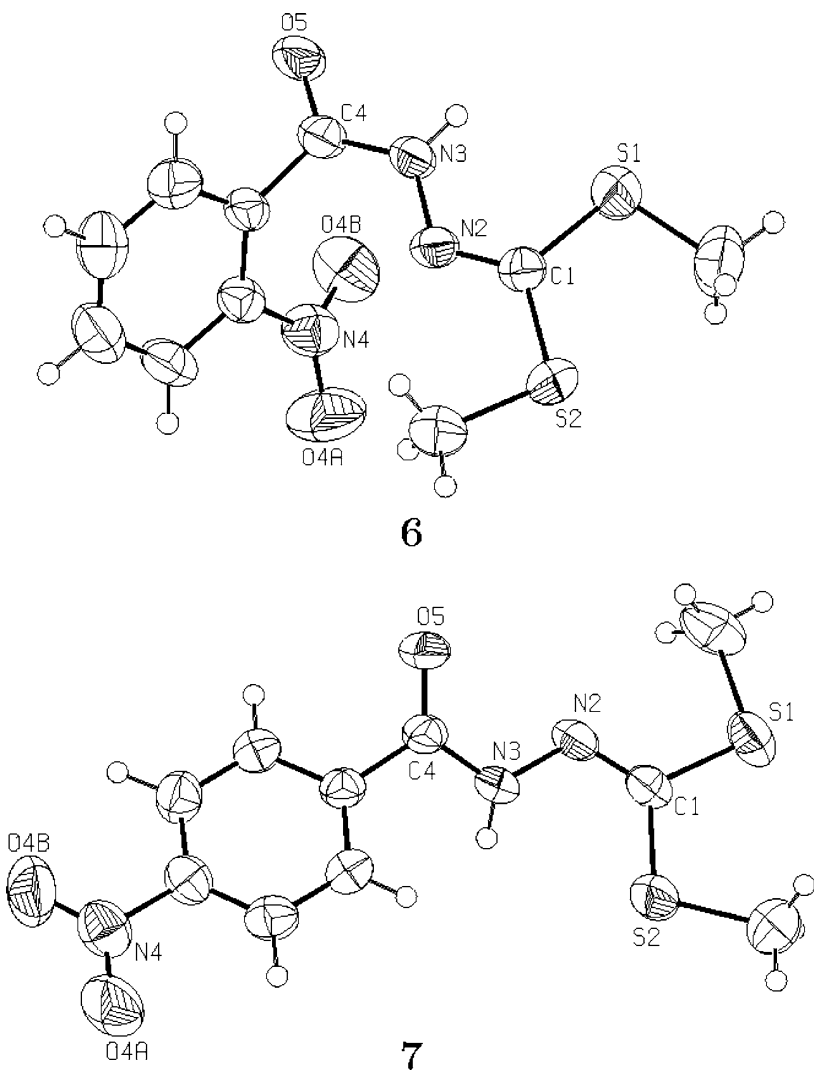

Fig. 1 ORTEP views of molecules 6 and 7 in their crystals. The ellipsoids are drawn at 50\% probability level [16]. Crystal data: monoclinic, $P 2_{1} / c, \quad Z=4$; with $a=8.138(1), \quad b=18.920(1)$, $c=9.270(1) \AA, \quad \beta=111.77(1)^{\circ}, \quad R_{1}=0.053\left(w R_{2}=0.177\right)$ for 2,044 observed reflections for 6; and $a=7.437(1), b=23.140(1)$, $c=8.874(1) \AA, \quad \beta=121.36(1)^{\circ}, R_{1}=0.043 \quad\left(w R_{2}=0.112\right)$ for 2,374 observed reflections for 7. The distances $\mathrm{C} 1-\mathrm{N} 2$ and $\mathrm{N} 2-\mathrm{N} 3$ are 1.272(3) and 1.390(3) $\AA$ for 6, and 1.276(3) and 1.401(2) $\AA$ and 7, indicating double bond character of the former bond. The dihedral angle between the phenyl ring and the carbonyl group is $58.0^{\circ}$ for $\mathbf{6}$ and $33.6^{\circ}$ for 7

are present in the spectrum mainly as a singlet of six protons.

Reaction yields and the physical constants of the newly synthesized compounds are given in Table 1.

\section{Microbiology}

The newly synthesized dimethylesters were examined in vitro for their tuberculostatic activity against $M$. tuberculosis $\mathrm{H}_{37} \mathrm{Rv}$ strain and two wild-type strains isolated from patients with tuberculosis: one (sp. 210) resistant to $p$-aminosalicylic acid (PAS), isonicotinic acid hydrazide (INH), ethambutol (ETB), and rifampicin (RFP) and the other (sp. 192) fully sensitive to the administered tuberculostatics (Table 2). Investigations were performed by a classical test-tube method of successive dilution in Youmans' modification of Proskauer and Beck's medium containing $10 \%$ of bovine 
Table 1 Characteristics of the newly synthesized dimethyl benzoylcarbonohydrazonodithioates $\mathbf{2 - 1 4}$

\begin{tabular}{llll}
\hline No. & Yield/\% & M.p. $/{ }^{\circ} \mathrm{C}$ & Solvent \\
\hline $\mathbf{2}$ & 95 & $73-75$ & EtOH \\
$\mathbf{3}$ & 97 & $83-85$ & EtOH/H ${ }_{2} \mathrm{O}$ \\
$\mathbf{4}$ & 93 & $113-115$ & $\mathrm{EtOH}$ \\
$\mathbf{5}$ & 90 & $131-133$ & $\mathrm{MeOH}$ \\
$\mathbf{6}$ & 74 & $141-144$ & $\mathrm{EtOH}$ \\
$\mathbf{7}$ & 87 & $154-146$ & EtOH \\
$\mathbf{8}$ & 46 & $173-175$ & Toluene \\
$\mathbf{9}$ & 87 & $153-155$ & $\mathrm{Chloroform}$ \\
$\mathbf{1 0}$ & 75 & $160-163$ & EtOH \\
$\mathbf{1 1}$ & 54 & $70-72$ & $\mathrm{Cyclohexane}$ \\
$\mathbf{1 2}$ & 81 & $158-160$ & EtOH \\
$\mathbf{1 3}$ & 67 & $97-99$ & EtOH \\
$\mathbf{1 4}$ & 95 & $150-152$ & MeOH \\
\hline
\end{tabular}

Table 2 Tuberculostatic activity of the tested compounds

\begin{tabular}{llll}
\hline No. & \multicolumn{2}{l}{$\mathrm{MIC} / \mu \mathrm{g} \mathrm{cm}^{-3}$} & \\
\cline { 2 - 4 } & $\mathrm{H}_{37} \mathrm{Rv}$ & 210 resistant & 192 sensitive \\
\hline $\mathbf{2}$ & 25 & 50 & 25 \\
$\mathbf{3}$ & 6.2 & 25 & 12.5 \\
$\mathbf{4}$ & 6.2 & 50 & 6.2 \\
$\mathbf{5}$ & 6.2 & 12.5 & 3.1 \\
$\mathbf{6}$ & 25 & 50 & 50 \\
$\mathbf{7}$ & 3.1 & 25 & 3.1 \\
$\mathbf{8}$ & 12.5 & 25 & 25 \\
$\mathbf{9}$ & 6.2 & 25 & 6.2 \\
$\mathbf{1 0}$ & 3.1 & 25 & 6.2 \\
$\mathbf{1 1}$ & 25 & 25 & 25 \\
$\mathbf{1 2}$ & 25 & 50 & 50 \\
$\mathbf{1 3}$ & 25 & 50 & 50 \\
$\mathrm{INH}$ & 0.5 & 1.1 & 0.5 \\
\hline
\end{tabular}

serum [17, 18]. Bacterial suspensions were prepared from 14-day-old cultures of slowly growing strains and from 48-h-old cultures of saprophytic strains [19, 20]. Solutions of compounds in ethylene glycol were tested. Stock solutions contained $10 \mathrm{mg}$ of compounds per $\mathrm{cm}^{3}$. Dilutions (in geometric progression) were prepared in Youmans' medium. The medium containing no investigated substances and containing isoniazid (INH) as reference drug were used for comparison. Incubation was performed at a temperature of $37{ }^{\circ} \mathrm{C}$. The MIC values were determined as minimum concentration inhibiting the growth of tested tuberculous strains in relation to the probe with no tested compound.

All tested compounds exhibited average or high tuberculostatic activity. However, their activity was lower than that obtained for the reference drug isoniazid (INH). Derivative 7, which has a nitro group in the 4-position of the benzene ring, was the most active compound toward $\mathrm{H}_{37} \mathrm{Rv}$ and 192 strains (MICs $3.1 \mu \mathrm{g} \mathrm{cm}^{-3}$ ). Its activity toward the resistant 210 strain was lower (MIC $25 \mu \mathrm{g} \mathrm{cm}^{-3}$ ). Derivative 5 , which has two chlorine atoms in the 3 - and 4-position, was the most active against resistant strain 210 (MIC $12.5 \mu \mathrm{g} \mathrm{cm}^{-3}$ ). It was also very active toward $\mathrm{H}_{37} \mathrm{Rv}$ and 192 strains (MIC 6.2 and $3.1 \mu \mathrm{g} \mathrm{cm}^{-3}$ ). Similar results were obtained for compound $\mathbf{1 0}$, which has a hydroxy group in the 4-position of the aromatic ring. It inhibited the growth of $M$. tuberculosis strains at concentrations of $3.1 \mu \mathrm{g} \mathrm{cm}^{-3}$ $\left(\mathrm{H}_{37} \mathrm{Rv}\right), 6.2 \mu \mathrm{g} \mathrm{cm}^{-3}(192)$, and $25 \mu \mathrm{g} \mathrm{cm}^{-3}(210)$.

Derivatives 3 (4-Cl), 4 (2,4-di-Cl), 8 (2-OH), and 9 (3-OH) generally exhibited average activity against all of the tested strains (MIC 6.2-25 $\mu \mathrm{g} \mathrm{cm}^{-3}$ ). Other compounds such as derivatives $\mathbf{2}(2-\mathrm{Cl}), \mathbf{6}\left(2-\mathrm{NO}_{2}\right), \mathbf{1 1}\left(4-\mathrm{OCH}_{3}\right)$, 12 (3,4,5-tri- $\left.\mathrm{OCH}_{3}\right)$, and $\mathbf{1 3}$, which has a 3,4-dimethoxyphenyl substituent separated from the carbonyl by a methylene group, have the lowest tuberculostatic activity (MIC 25-50 $\mathrm{g} \mathrm{cm}^{-3}$ ).

On the basis of the above results we conclude that electronegative substituents $\left(\mathrm{NO}_{2}, \mathrm{Cl}, \mathrm{OH}\right)$ in the 4-position of the aromatic ring caused higher tuberculostatic activity, whereas derivatives with substituents in the 2-position exhibit moderate or low activity. Similar results were obtained for compounds with one or more methoxy groups as a substituent. It is very significant that derivative 6, which has an $\mathrm{NO}_{2}$ group in the 2-position, possesses structural factors allowing it to form intramolecular hydrogen bonds and to adopt a planar structure (Fig. 1) and exhibit lower tuberculostatic activity. Compound 7, which cannot adopt a planar structure, shows the highest activity among the tested derivatives.

The most active compounds $\mathbf{3 - 5}, \mathbf{7}, \mathbf{9}$, and $\mathbf{1 0}$ were screened in widened tuberculostatic tests using ten acidresistant strains of Mycobacterium genus (Table 3) and they exhibited activity against only a few strain types: $\mathrm{H}_{37} \mathrm{Rv}$, $\mathrm{An}_{5}$, Wells, Kirchberg, and Kansasii. In those tests derivatives 5 (3,4-di-Cl), $7\left(4-\mathrm{NO}_{2}\right)$, and $\mathbf{1 0}(4-\mathrm{OH})$ generally exhibited the highest activity (MIC $6.2-25 \mu \mathrm{g} \mathrm{cm}^{-3}$ ). All compounds exhibited rather weak activity toward Scrofulaceum, Intracellularum, Fortuitum, Smegmatis, and Phlei strains. However, their activity against Kirchberg and Kansasii strains was higher than that exhibited by isoniazid (INH).

\section{Cytotoxicity}

Compounds 5, 7, and 10, the most active toward M. tuberculosis strains, were tested for cytotoxicity against human non-small lung cancer cell line A549 and human colon cancer cell line HCT116. Both lines were maintained 
Table 3 Widened tuberculostatic tests for chosen dimethylesters

\begin{tabular}{llllllll}
\hline Bacteria strain & \multicolumn{2}{l}{$\mathrm{MIC} / \mu \mathrm{g} \mathrm{cm}^{-3}$} & & & & \\
\cline { 2 - 7 } & $\mathbf{3}$ & $\mathbf{4}$ & $\mathbf{5}$ & $\mathbf{7}$ & $\mathbf{9}$ & $\mathbf{1 0}$ & $\mathrm{INH}$ \\
\hline $\mathrm{H}_{37} \mathrm{Rv}$ & 12.5 & 6.2 & 6.2 & 6.2 & 6.2 & 6.2 & 0.5 \\
$\mathrm{An}_{5}$ & 12.5 & 6.2 & 12.5 & 6.2 & 6.2 & 6.2 & 1.1 \\
Wells & 12.5 & 12.5 & 6.2 & 6.2 & 6.2 & 12.5 & 0.5 \\
Kirchberg & 25 & 100 & 12.5 & 50 & 50 & 50 & 156 \\
Kansasii & 25 & 25 & 6.2 & 25 & 12.5 & 25 & 39 \\
Scrofulaceum & 100 & 25 & 25 & 100 & 25 & 50 & 78 \\
Intracellularum & 50 & 100 & 100 & 100 & 25 & 100 & 78 \\
Fortuitum & 100 & 100 & 100 & 100 & 25 & 100 & 78 \\
Smegmatis & 100 & 100 & 100 & 50 & 50 & 100 & 39 \\
Phlei & 100 & 100 & 100 & 100 & 100 & 100 & 39 \\
\hline
\end{tabular}

in RPMI1640 or McCoy's 5A medium, respectively, supplemented with $10 \%$ fetal bovine serum, $2 \mathrm{mM}$ L-glutamine, and antibiotics (100 units $/ \mathrm{cm}^{3}$ of penicillin and $100 \mathrm{mg} \mathrm{cm}^{-3}$ of streptomycin) at $37{ }^{\circ} \mathrm{C}$ in a $5 \% \mathrm{CO}_{2} /$ air atmosphere [21]. Cells were screened routinely for mycoplasma by the PCR method with a Mycoplasma Plus PCR Primer Set (Stratagene, La Jolla, CA, USA) [22]. The cytotoxicity of the tested compounds was determined by the MTT viability assay with exponentially growing cells and continuous drug exposure $(120 \mathrm{~h})$. After drug treatment cells were exposed to the MTT, a tetrazolium salt, for $4 \mathrm{~h}$ at $37^{\circ} \mathrm{C}$, and the formation of formazan was measured by a VICTOR ${ }^{3} \mathrm{~V}$ microplate reader (Wallac Perkin). The concentrations required to inhibit cell growth by $50 \%$ compared to untreated controls were determined from the curves plotting survival as a function of dose using the SlideWrite program (Fig. 2). All values are means of at least two independent experiments, each done in duplicate (Table 4). Cisplatin (Cis-Pt) and doxotubicin (Dox) were used as control cytostatic drugs. $I C_{50}$ values determined in the A549 cell line were $0.63 \pm 0.018 \mu \mathrm{M}$ (Cis-Pt) and $0.008 \pm 0.0011 \mu \mathrm{M}$ (Dox).

Tested compounds exhibited rather low cytotoxic activity. Derivatives $\mathbf{7}$ and $\mathbf{1 0}$ inhibited the growth of the both cell lines by $50 \%$ at concentrations greater than $100 \mu \mathrm{M}$. Lower values of $I C_{50}$ were obtained for compound 5: $69 \mu \mathrm{M}$ (A549) and $28 \mu \mathrm{M}$ (HCT116). However, $I C_{50}$ values (ca. $100 \mu \mathrm{M}$ ) are ten times higher than MICs $\left(3.1 \mu \mathrm{g} \mathrm{cm}^{-3}\right.$ ) for compounds $\mathbf{7}$ and $\mathbf{1 0}$ and three times higher for compound $\mathbf{5}\left(I C_{50}\right.$ ca. $30 \mu \mathrm{M}, \quad \mathrm{MIC}$ $\left.3.1 \mu \mathrm{g} \mathrm{cm}^{-3}\right)$. Therefore the tuberculostatic activity of those derivatives does not seem to be caused by their cytotoxicity.

In summary, the synthesized and tested compounds exhibit promising tuberculostatic activity. Unexpectedly we have found no correlation between the rather planar structure of compound $\mathbf{6}$ and its activity toward M. tuberculosis.
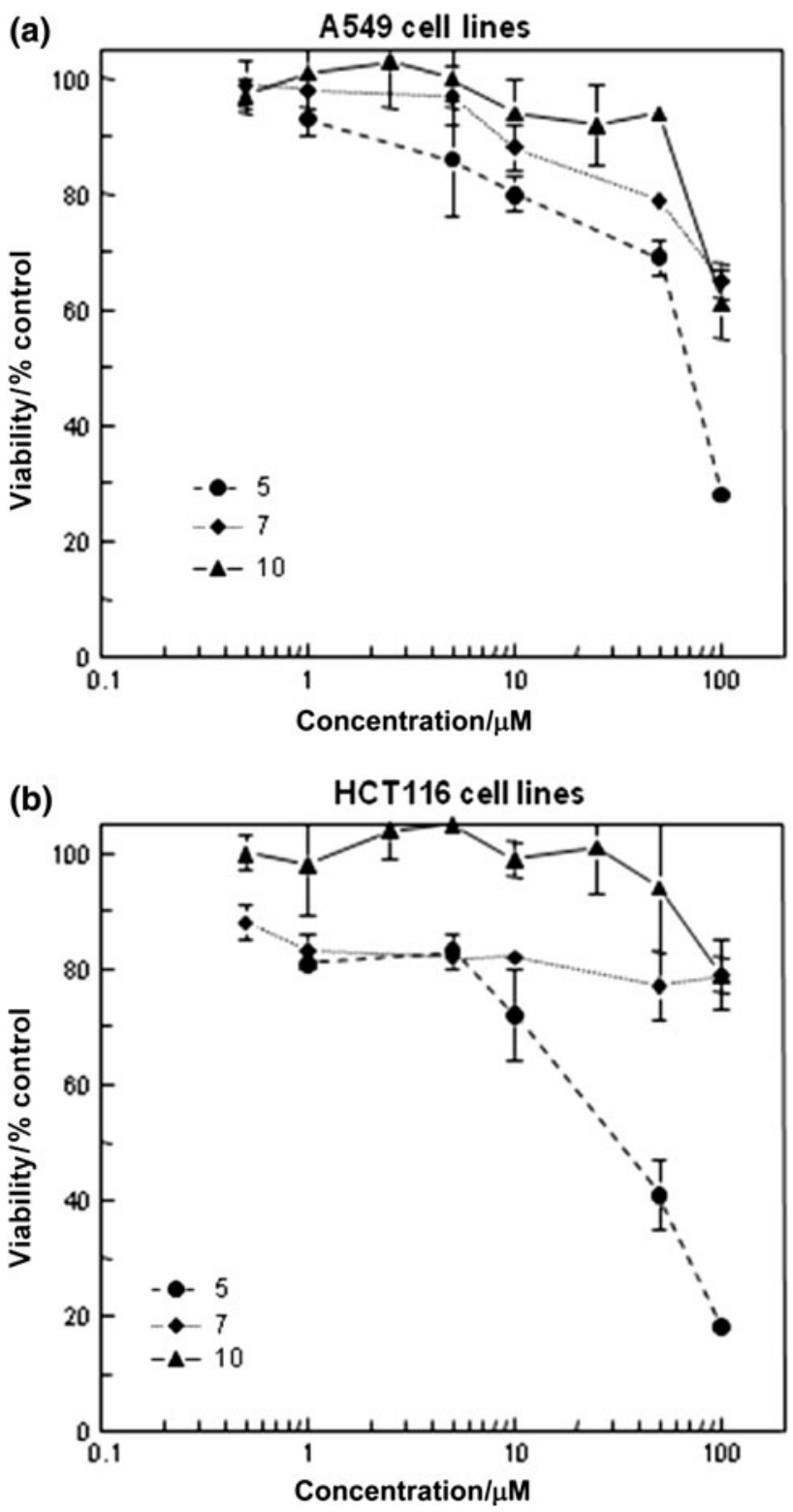

Fig. 2 Effect of compounds 5, 7, and $\mathbf{1 0}$ on A549 (a) and HCT116 human cell lines (b)

Table 4 Cytotoxicity of compounds 5, 7, and $\mathbf{1 0}$

\begin{tabular}{lll}
\hline No. & $I C_{50} / \mathrm{mM}$ & \\
\cline { 2 - 3 } & $\mathrm{A} 549$ & HCT116 \\
\hline $\mathbf{5}$ & $69 \pm 23$ & $28 \pm 11$ \\
$\mathbf{7}$ & $>100$ & $\gg 100$ \\
$\mathbf{1 0}$ & $>100($ ca. 126$)$ & $\gg 100$ (ca. 380) \\
\hline
\end{tabular}

The structure of the most active compound $\mathbf{7}$ has no ability to form hydrogen bonds or to adopt a planar structure. Therefore, its activity has to be associated with other structural factors. Taking into consideration the structural 
similarity of compound $\mathbf{7}$ and INH, the substituent in the 4-position could be that factor, and susceptibility to activation by catalase-peroxidase KatG could limit the tuberculostatic activity of all the synthesized derivatives.

\section{Experimental}

All materials and solvents were of analytical reagent grade. Thin-layer chromatography was performed on Merck Kieselgel $60 \mathrm{~F}_{254}$ plates and visualized with UV. The results of elemental analyses (\% C, H, N) for all compounds obtained were in good agreement with calculated values within $\pm 0.3 \%$. ${ }^{1} \mathrm{H}$ and ${ }^{13} \mathrm{C}$ NMR spectra in $\mathrm{CDCl}_{3}$ or DMSO- $d_{6}$ were recorded on Varian Gemini $(200 \mathrm{MHz})$ instruments. IR spectra were determined as $\mathrm{KBr}$ pellets of the solids on a Satellite FT-IR spectrophotometer. Electrospray MS analyses for compounds $\mathbf{2}$ and $\mathbf{3}$ were performed on an HCT Ultra Bruker Daltonics spectrometer operating in positive- and negative-ion modes (sheath gas $\mathrm{N}_{2}$, temperature $300{ }^{\circ} \mathrm{C}$, flow $7 \mathrm{dm}^{3} / \mathrm{min}$, pressure $10 \mathrm{psi}$ $(689.48 \mathrm{hPa})$; capillary voltage in positive ion mode $+4 \mathrm{kV}$, in negative ion mode $-4 \mathrm{kV}$ ). Compounds samples were prepared in a chloroform/methanol (1:1) mixture. Melting points were determined on a BOETIUS apparatus. Benzohydrazides were prepared according to known procedures, and yields and melting points were found to be identical with those described in the literature [23-32].

\section{General procedure for the preparation of dimethyl benzoylcarbonohydrazonodithioates 1-14}

To a suspension of the appropriate benzohydrazide (0.03 mol) in $10 \mathrm{~cm}^{3}$ of ethanol, $2 \mathrm{~cm}^{3}$ of carbon disulfide $(0.03 \mathrm{~mol})$ was added in a few portions. Then a solution of $3.7 \mathrm{~g}$ of potassium hydroxide $(0.06 \mathrm{~mol})$ in $5 \mathrm{~cm}^{3}$ of water was added. After 15 min of stirring $4 \mathrm{~cm}^{3}$ of methyl iodide $(0.06 \mathrm{~mol})$ was added dropwise. The solution was cooled and the precipitate of potassium iodide was filtered off. The filtrate was diluted with $50 \mathrm{~cm}^{3}$ of ice-cold water and extracted with chloroform. Chloroform extracts were collected, dried with magnesium sulfate, and evaporated. The crude oily product was washed with dry diethyl ether, filtered, and recrystallized from an appropriate solvent (Table 1).

Dimethyl benzoylcarbonohydrazonodithioate (1)

Yield 90\%, m.p.: $85-86{ }^{\circ} \mathrm{C}$ (Ref. [33] 85-86 ${ }^{\circ} \mathrm{C}$ ).

Dimethyl 2-chlorobenzoylcarbonohydrazonodithioate

$\left(2, \mathrm{C}_{10} \mathrm{H}_{11} \mathrm{ClN}_{2} \mathrm{OS}_{2}\right)$

IR (KBr): $\bar{v}=3,144 ; 1,643 ; 1,552 ; 1,424 ; 1,636 ; 763$; $603 \mathrm{~cm}^{-1}$; ${ }^{1} \mathrm{H}$ NMR $\left(\mathrm{CDCl}_{3}\right): \delta=2.43\left(\mathrm{~s}, 3 \mathrm{H}, \mathrm{SCH}_{3}\right)$, $2.70\left(\mathrm{~s}, 3 \mathrm{H}, \mathrm{SCH}_{3}\right), 7.28-7.53$ and $7.68-7.95(2 \mathrm{~m}, 4 \mathrm{H}$,
$\mathrm{Ph}), 9.19$ (brs, $1 \mathrm{H}, \mathrm{NH}) \mathrm{ppm} ;{ }^{13} \mathrm{C}$ NMR (DMSO- $d_{6}$ ): $\delta=14.7,15.0,127.2,128.7,129.8,130.6,131.3,135.7$, $160.9, \quad 162.1 \mathrm{ppm} ; \quad \mathrm{MS} \quad(+): \quad m / z=571 \quad(27 \%$, $\left.[2 \mathrm{M}+\mathrm{Na}-2 \mathrm{H}]^{+}\right), 297\left(100 \%,[\mathrm{M}+\mathrm{Na}]^{+}\right) ; \mathrm{MS}(-)$ : $m / z=569 \quad\left(100 \%, \quad[2 \mathrm{M}+\mathrm{Na}-4 \mathrm{H}]^{-}\right), \quad 273 \quad(30 \%$, $\left.[\mathrm{M}-2 \mathrm{H}]^{-}\right)$.

Dimethyl 4-chlorobenzoylcarbonohydrazonodithioate $\left(3, \mathrm{C}_{10} \mathrm{H}_{11} \mathrm{ClN}_{2} \mathrm{OS}_{2}\right)$

IR $(\mathrm{KBr}): \bar{v}=3,264 ; 1,664 ; 1,492 ; 1,360 ; 1,083 ; 1,003$; $656 \mathrm{~cm}^{-1} ;{ }^{1} \mathrm{H}$ NMR (DMSO- $\left.d_{6}\right): \delta=2.53\left(\mathrm{~s}, 3 \mathrm{H}, \mathrm{SCH}_{3}\right.$ ), 2.78 (s, 3H, $\left.\mathrm{SCH}_{3}\right), 7.55$ (d, 2H, Ph, $\left.J=8.1 \mathrm{~Hz}\right), 7.83$ (d, $2 \mathrm{H}, \mathrm{Ph}, J=8.4 \mathrm{~Hz}$ ), 10.86 (brs, $1 \mathrm{H}, \mathrm{NH}) \mathrm{ppm} ;{ }^{13} \mathrm{C} \mathrm{NMR}$ $\left(\mathrm{DMSO}-d_{6}\right): \delta=14.6,15.1,128.7,129.7,132.6,136.4$, $161.8,163.7 \mathrm{ppm}$.

Dimethyl 2,4-dichlorobenzoylcarbonohydrazonodithioate $\left(4, \mathrm{C}_{10} \mathrm{H}_{10} \mathrm{Cl}_{2} \mathrm{~N}_{2} \mathrm{OS}_{2}\right)$

IR $(\mathrm{KBr}): \bar{v}=3,160 ; \quad 1,643 ; 1,520 ; 1,296 ; 1,056$; $832 \mathrm{~cm}^{-1} ;{ }^{1} \mathrm{H}$ NMR (DMSO-d $\left.)_{6}\right): \delta=2.49 \quad(\mathrm{~s}, \quad 3 \mathrm{H}$, $\left.\mathrm{SCH}_{3}\right), 2.53\left(\mathrm{~s}, 3 \mathrm{H}, \mathrm{SCH}_{3}\right), 7.43-7.51(\mathrm{~m}, 2 \mathrm{H}, \mathrm{Ph}), 7.66-$ $7.71(\mathrm{~m}, 1 \mathrm{H}, \mathrm{Ph}), 10.90$ (brs, $1 \mathrm{H}, \mathrm{NH}) \mathrm{ppm} ;{ }^{13} \mathrm{C}$ NMR $\left(\right.$ DMSO- $\left.d_{6}\right): \delta=14.7,15.1,127.5,129.4,129.9,131.0$, 132.0, 135.1, 161.3, $167.5 \mathrm{ppm}$.

Dimethyl 3,4-dichlorobenzoylcarbonohydrazonodithioate $\left(\mathbf{5}, \mathrm{C}_{10} \mathrm{H}_{10} \mathrm{Cl}_{2} \mathrm{~N}_{2} \mathrm{OS}_{2}\right)$

IR $(\mathrm{KBr}): \bar{v}=3,148 ; 1,632 ; 1,536 ; 1,472 ; 1,296 ; 1,056$; $720 \mathrm{~cm}^{-1} ;{ }^{1} \mathrm{H}$ NMR (DMSO- $\left.d_{6}\right): \delta=2.53\left(\mathrm{~s}, 3 \mathrm{H}, \mathrm{SCH}_{3}\right.$ ), 2.54 (s, $\left.3 \mathrm{H}, \mathrm{SCH}_{3}\right), 7.78$ (d, $\left.2 \mathrm{H}, \mathrm{Ph}, J=1.5 \mathrm{~Hz}\right), 8.03$ (s, $1 \mathrm{H}, \mathrm{Ph}$ ), 11.0 (brs, $1 \mathrm{H}, \mathrm{NH}) \mathrm{ppm} ;{ }^{13} \mathrm{C}$ NMR (DMSO- $d_{6}$ ): $\delta=14.6,15.1,128.0,129.6,131.1,131.5,134.2,134.4$, 160.6, $164.6 \mathrm{ppm}$.

Dimethyl 2-nitrobenzoylcarbonohydrazonodithioate

$\left(6, \mathrm{C}_{10} \mathrm{H}_{11} \mathrm{~N}_{3} \mathrm{O}_{3} \mathrm{~S}_{2}\right)$

IR $(\mathrm{KBr}): \bar{v}=3,160 ; 1,652 ; 1,520 ; 1,376 ; 944 \mathrm{~cm}^{-1} ;{ }^{1} \mathrm{H}$ NMR $\left(\mathrm{CDCl}_{3}\right): \delta=1.94\left(\mathrm{~s}, 3 \mathrm{H}, \mathrm{SCH}_{3}\right), 2.50(\mathrm{~s}, 3 \mathrm{H}$, $\left.\mathrm{SCH}_{3}\right), 7.55-7.80(\mathrm{~m}, 3 \mathrm{H}, \mathrm{Ph}), 8.10-8.18(\mathrm{~m}, 1 \mathrm{H}, \mathrm{Ph}), 9.19$ (brs, $1 \mathrm{H}, \mathrm{NH}$ ) ppm; ${ }^{13} \mathrm{C}$ NMR (DMSO- $d_{6}$ ): $\delta=14.8,15.1$, 123.6, 129.2, 130.5, 134.1, 134.8, 148.9, 161.8, $168.1 \mathrm{ppm}$.

Dimethyl 4-benzoylcarbonohydrazonodithioate

$\left(7, \mathrm{C}_{10} \mathrm{H}_{11} \mathrm{~N}_{3} \mathrm{O}_{3} \mathrm{~S}_{2}\right)$

IR $(\mathrm{KBr}): \bar{v}=3,176 ; 3,000 ; 1,643 ; 1,600 ; 1,523 ; 1,344$; 1,$280 ; 860 ; 720 \mathrm{~cm}^{-1} ;{ }^{1} \mathrm{H} \mathrm{NMR}\left(\mathrm{CDCl}_{3}\right): \delta=2.59(\mathrm{~s}, 6 \mathrm{H}$, $\left.2 \mathrm{SCH}_{3}\right), 7.94-8.05(\mathrm{~m}, 2 \mathrm{H}, \mathrm{Ph}), 8.21-8.40(\mathrm{~m}, 2 \mathrm{H}, \mathrm{Ph})$, 9.35-9.58 (brs, $1 \mathrm{H}, \mathrm{NH}) \mathrm{ppm} ;{ }^{13} \mathrm{C}$ NMR (DMSO- $d_{6}$ ): $\delta=14.5, \quad 15.1, \quad 123.9, \quad 129.2, \quad 139.6, \quad 149.3, \quad 161.1$, $164.9 \mathrm{ppm}$.

Dimethyl 2-hydroxybenzoylcarbonohydrazonodithioate $\left(\mathbf{8}, \mathrm{C}_{10} \mathrm{H}_{12} \mathrm{~N}_{2} \mathrm{O}_{2} \mathrm{~S}_{2}\right)$

IR $(\mathrm{KBr}): \bar{v}=3,056 ; 1,632 ; 1,543 ; 1,456 ; 1,312 ; 1,232$; 896; $752 \mathrm{~cm}^{-1} ;{ }^{1} \mathrm{H}$ NMR (DMSO- $d_{6}$ ): $\delta=2.56(\mathrm{~s}, 6 \mathrm{H}$, $2 \mathrm{SCH}_{3}$ ), 6.73-7.80 (m, 4H, Ph), 9.80-10.20 (brs, 1H, NH) 
ppm; ${ }^{13}$ C NMR (DMSO- $d_{6}$ ): $\delta=15.0,117.1,117.7,120.0$, $130.9,133.6,151.7,156.5,161.0 \mathrm{ppm}$.

\section{Dimethyl 3-hydroxybenzoylcarbonohydrazonodithioate}

$\left(9, \mathrm{C}_{10} \mathrm{H}_{12} \mathrm{~N}_{2} \mathrm{O}_{2} \mathrm{~S}_{2}\right)$

IR $(\mathrm{KBr}): \bar{v}=3,152 ; 1,643 ; 1,600 ; 1,483 ; 1,456 ; 1,296$; 1,$232 ; 832 ; 736 \mathrm{~cm}^{-1} ;{ }^{1} \mathrm{H}$ NMR $\left(\mathrm{CDCl}_{3}\right): \delta=2.55(\mathrm{~s}, 3 \mathrm{H}$, $\left.\mathrm{SCH}_{3}\right), 2.57$ (s, 3H, $\left.\mathrm{SCH}_{3}\right), 7.02-7.38(2 \mathrm{~m}, 4 \mathrm{H}, \mathrm{Ph}), 7.57$ (s, 1H, OH), 9.46-9.61 (brs, $1 \mathrm{H}, \mathrm{NH}) \mathrm{ppm} ;{ }^{13} \mathrm{C}$ NMR (DMSO- $d_{6}$ ): $\delta=14.7,15.0,114.6,118.2,118.6,129.7$, 135.2, 155.3, 157.6, $163.9 \mathrm{ppm}$.

\section{Dimethyl 4-hydroxybenzoylcarbonohydrazonodithioate}

$\left(\mathbf{1 0}, \mathrm{C}_{10} \mathrm{H}_{12} \mathrm{~N}_{2} \mathrm{O}_{2} \mathrm{~S}_{2}\right.$ )

IR $(\mathrm{KBr}): \bar{v}=3,136 ; 1,643 ; 1,592 ; 1,483 ; 1,440 ; 1,280$; 1,$232 ; 896 ; 752 \mathrm{~cm}^{-1} ;{ }^{1} \mathrm{H}$ NMR (DMSO- $\left.d_{6}\right): \delta=2.00(\mathrm{~s}$, $\left.6 \mathrm{H}, 2 \mathrm{SCH}_{3}\right), 6.20-6.75$ and 7.00-7.60 (2d, $\left.4 \mathrm{H}, \mathrm{Ph}\right), 9.26-$ $10.26(\mathrm{~d}, 2 \mathrm{H}, \mathrm{OH}$ and $\mathrm{NH}) \mathrm{ppm} ;{ }^{13} \mathrm{C}$ NMR (DMSO- $\left.d_{6}\right)$ : $\delta=14.7, \quad 15.0, \quad 115.2, \quad 124.3,129.7,151.7,160.7$, $161.0 \mathrm{ppm}$.

\section{Dimethyl 4-methoxybenzoylcarbonohydrazonodithioate}

(11, $\left.\mathrm{C}_{11} \mathrm{H}_{14} \mathrm{~N}_{2} \mathrm{O}_{2} \mathrm{~S}_{2}\right)$

IR $(\mathrm{KBr}): \bar{v}=3,312 ; 1,664 ; 1,600 ; 1,563 ; 1,452 ; 1,260$;

$1,024 \mathrm{~cm}^{-1} ;{ }^{1} \mathrm{H} \mathrm{NMR}\left(\mathrm{CDCl}_{3}\right): \delta=2.50\left(\mathrm{~s}, 6 \mathrm{H}, 2 \mathrm{SCH}_{3}\right)$, $3.80\left(\mathrm{~s}, 3 \mathrm{H}, \mathrm{OCH}_{3}\right), 6.70-7.06$ and $7.60-7.93(2 \mathrm{~m}, 4 \mathrm{H}$, $\mathrm{Ph}$ ), 9.20-9.56 (brs, 1H, NH) ppm; ${ }^{13} \mathrm{C}$ NMR (DMSO- $d_{6}$ ): $\delta=14.7, \quad 15.0, \quad 55.7, \quad 113.7, \quad 125.9, \quad 129.6, \quad 162.0$, $162.6 \mathrm{ppm}$.

\section{Dimethyl 3,4,5-trimethoxybenzoylcarbonohydrazonodithioate}

$\left(12, \mathrm{C}_{13} \mathrm{H}_{18} \mathrm{~N}_{2} \mathrm{O}_{4} \mathrm{~S}_{2}\right)$

IR $(\mathrm{KBr}): \bar{v}=3,176 ; 3,000 ; 1,640 ; 1,584 ; 1,532 ; 1,340$; 1,$232 ; 1,120 \mathrm{~cm}^{-1} ;{ }^{1} \mathrm{H}$ NMR $\left(\mathrm{CDCl}_{3}\right): \delta=2.58(\mathrm{~s}, 6 \mathrm{H}$, $\left.2 \mathrm{SCH}_{3}\right), 3.88-3.96\left(\mathrm{~m}, 9 \mathrm{H}, 3 \mathrm{OCH}_{3}\right), 7.07$ (s, $\left.2 \mathrm{H}, \mathrm{Ph}\right), 9.36$ $(\mathrm{s}, 1 \mathrm{H}, \mathrm{NH}) \mathrm{ppm} ;{ }^{13} \mathrm{C}$ NMR (DMSO- $\left.d_{6}\right): \delta=14.6,15.1$, $56.28,60.4,105.2,128.9,140.6,152.9,162.0 \mathrm{ppm}$.

Dimethyl 2-(3,4-dimethoxyphenyl)acetylcarbono-

hydrazonodithioate $\left(13, \mathrm{C}_{13} \mathrm{H}_{18} \mathrm{~N}_{2} \mathrm{O}_{3} \mathrm{~S}_{2}\right)$

IR $(\mathrm{KBr}): \bar{v}=3,152 ; 1,664 ; 1,520 ; 1,264 ; 1,216 ; 1,136$; $1,024 \mathrm{~cm}^{-1} ;{ }^{1} \mathrm{H} \mathrm{NMR}\left(\mathrm{CDCl}_{3}\right): \delta=2.47\left(\mathrm{~s}, 6 \mathrm{H}, 2 \mathrm{SCH}_{3}\right)$, $3.43-4.10\left(\mathrm{~m}, 8 \mathrm{H}, 2 \mathrm{OCH}_{3}\right.$ and $\left.\mathrm{CH}_{2}\right), 6.80(\mathrm{~s}, 3 \mathrm{H}, \mathrm{Ph})$, 8.63-9.07 (brs, $1 \mathrm{H}, \mathrm{NH}$ ) ppm; ${ }^{13} \mathrm{C}$ NMR (DMSO- $d_{6}$ ): $\delta=14.8,15.0,39.6,55.8,112.0,113.2,121.4,128.6$, $147.8,148.7,154.7,172.5 \mathrm{ppm}$.

\section{Dimethyl pyrazine-2-carbonylcarbonohydrazonodithioate} $\left(14, \mathrm{C}_{8} \mathrm{H}_{10} \mathrm{~N}_{4} \mathrm{OS}_{2}\right)$

IR $(\mathrm{KBr}): \bar{v}=3,243 ; 1,700 ; 1,508 ; 1,392 ; 1,156$; $1,072 \mathrm{~cm}^{-1} ; \quad{ }^{1} \mathrm{H} \quad \mathrm{NMR} \quad\left(\mathrm{CDCl}_{3}\right): \delta=2.55 \quad(\mathrm{~s}, \quad 6 \mathrm{H}$, $\left.2 \mathrm{SCH}_{3}\right), 8.00,8.57$, and $9.48(3 \mathrm{~s}, 3 \mathrm{H}$, pyrazine), 10.95 $(\mathrm{s}, 1 \mathrm{H}, \mathrm{NH}) \mathrm{ppm} ;{ }^{13} \mathrm{C}$ NMR (DMSO- $\left.d_{6}\right): \delta=15.0,15.3$, 143.9, 144.2, 148.4, 157.1, $157.7 \mathrm{ppm}$.
Open Access This article is distributed under the terms of the Creative Commons Attribution Noncommercial License which permits any noncommercial use, distribution, and reproduction in any medium, provided the original author(s) and source are credited.

\section{References}

1. World Health Organization (2008) Global tuberculosis control surveillance, planning, financing. Available via http://www.who. int/tb/publications/global_report/2008/en/index.html. Accessed 25 July 2011

2. Matteelli A, Migliori GB, Cirillo D, Girard E, Raviglione M (2007) Expert Rev Anti Infect Ther 5:857

3. Gandhi NR, Moll A, Sturm AW, Pawinski R, Govender T, Lalloo U, Zeller K, Andrews J, Friedland G (2006) Lancet 368:1575

4. Lang H, Quaglio G, Olesen OF (2010) Tuberculosis 90:1

5. Mdluli K, Spigelman M (2006) Curr Opin Pharmacol 6:459

6. Klopman G, Fercu D, Jacob J (1996) Chem Phys 204:181

7. Silva FP Jr, Ellena J, de Lima Ferreira M, Mascarenhas YP, de Souza MVN, Vasconcelos TRA, Wardell JL, Wardell SMSV (2006) J Mol Struct 788:63

8. Abdel-Aziz M, Abdel-Rahman HM (2010) Eur J Med Chem 45:3384

9. Karali N, Gürsoy A, Kandemirli F, Shvets N, Kaynak FB, Özbey S, Kovalishyn V, Dimoglo A et al (2007) Bioorg Med Chem 15:5888

10. Bedia K-K, Elçin O, Seda U, Fatma K, Nathaly S, Sevim R, Dimoglo A et al (2006) Eur J Med Chem 41:1253

11. Pavan FR, Maia PI, da S, Leite SRA, Deflon VM, Batista AA, Sato DN, Franzblau SG, Leite CQF et al (2010) Eur J Med Chem 45:1898

12. Orlewska C, Foks H, Janowiec M, Zwolska Z (1995) Pharmazie 50:563

13. Orlewska C, Foks H, Sowiński P, Martynowski D, Olczak A, Główka ML (2001) Polish J Chem 75:1237

14. Główka ML, Martynowski D, Olczak A, Orlewska C, Foks H, Bojarska J, Szczesio M, Gołka J (2005) J Chem Cryst 35:477

15. Olczak A, Główka ML, Gołka J, Szczesio M, Bojarska J, Kozłowska K, Foks H, Orlewska C (2007) J Mol Struct 830:171

16. Spek AL (2003) J Appl Cryst 36:7

17. Youmans GP (1947) Am Rev Tuberc 56:376

18. Youmans GP, Youmans AS (1949) J Bacteriol 58:247

19. Atlas RM, Singler JW (1995) Media for clinical microbiology. CRC, Boca Raton, p 313

20. Foks H, Buraczewska M, Manowska W, Sawlewicz J (1971) Dissert Pharm Pharmacol 23:49

21. Greer JP, Wintrobe MM (2009) Wintrobe's clinical hematology. Lippincott Williams \& Wilkins, Philadelphia, p 52

22. Welti M, Jaton K, Altweg M, Sahli R, Wenger A, Bille J (2003) Diagn Microbiol Infect Dis 45:85

23. Curtius T, Struve G (1894) J Prakt Chem 50:295

24. Sah PPT (1940) Recl Trav Chim Pays-Bas 59:1029

25. Kahl R (1904) Chem Zentralbl 11:1493

26. Yale HL, Losee K, Martins J, Holsing M, Perry FM, Bernstein J (1953) J Am Chem Soc 75:1933

27. Curtius T, Trachmann R (1895) J Prakt Chem 51:168

28. Curtius T, Struve A, Radenhausen R (1895) J Prakt Chem 52:234

29. Curtius T, Melsbach H (1910) J Prakt Chem 81:536

30. Pepe R (1930) J Prakt Chem 126:241

31. Aggarwal JS, Khera ID, Ray JN (1930) J Chem Soc 2354

32. Foks H, Sawlewicz J (1964) Acta Polon Pharm 21:458

33. Rüfenacht K (1974) Helv Chim Acta 57:23 